Naonori Nagaya*

\title{
Directionals, topography, and cultural construals of landscape in Lamaholot
}

https://doi.org/10.1515/lingvan-2020-0022

Received April 20, 2020; accepted May 26, 2021

\begin{abstract}
This paper investigates "directionals" or geocentric spatial terms in Lamaholot, examining the interaction between directionals, topographic environment, and cultural construals of landscape. Lamaholot is an Austronesian language of eastern Indonesia spoken on the volcanic island of Flores. The Lewotobi dialect, with which this paper is concerned, is spoken on the coastal area between Mt. Lewotobi and the Solor Sea. Reflective of this topographic environment, this language has "directionals" or grammatical terms defined with respect to landmarks: rae 'mountainward', lau 'seaward', wali 'parallel with the coast', teti 'upward', and lali 'downward'. After describing how the spatial orientation represented by directionals is embedded in linguistic and sociocultural practices in Lamaholot-speaking communities, this paper shows that directionals exhibit intriguing diversity in interpretation and morphosyntax: they constitute a coordinate system for geocentric frame of reference, refer to different directions depending on different construals of landscape, and can appear in various syntactic positions. It is argued that this diversity can be understood in terms of a complex interplay of topographic environment, sociocultural practices, language uses, and linguistic repertoire, as assumed in the Sociotopographic Model (Palmer, Bill, Jonathon Lum, Jonathan Schlossberg \& Alice Gaby. 2017. How does the environment shape spatial language? Evidence for sociotopography. Linguistic Typology 21(3). 457-491). Thus, the directional system in Lamaholot makes a strong case for a sociotopographic approach to spatial language.
\end{abstract}

Keywords: Austronesian; directional; frames of reference; Lamaholot; sociotopography

\section{Introduction}

This paper presents a case study of geocentric spatial terms in the Lamaholot language of eastern Indonesia (ISO 639-3 slp). Lamaholot belongs to the Central Malayo-Polynesian branch of the Austronesian language family (Blust 1993) and is spoken in the eastern part of Flores Island and on neighboring islands (Map 1). The Lewotobi dialect (ISO 639-3 lwt), with which this paper is concerned, is the most westerly Lamaholot dialect and is spoken by approximately 6,000 speakers in Kecamatan Ile Bura. It is spoken in villages around Mt. Lewotobi (Map 2), which is a twin volcano consisting of Lewotobi Perempuan (1,703 m) and Lewotobi Lakilaki $(1,584 \mathrm{~m})$. This mountain serves as the most significant local landmark in the region. The descriptions to follow are based on my fieldwork in Nurabelen, a coastal village sandwiched by Mt. Lewotobi and the Solor Sea (see Figures 1 and 2; Nagaya 2011).

The Lewotobi dialect of Lamaholot has a geocentric orientation system, also known as a "directional" system, consisting of five grammatical terms, given in (1). These five directionals are divided into two groups depending on which axis they are based on: the mountain-sea axis or the up-down axis.

*Corresponding author: Naonori Nagaya, Department of Linguistics, The University of Tokyo, 7-3-1 Hongo, Bunkyo, Tokyo 113-0033, Japan, E-mail: nagaya@l.u-tokyo.ac.jp. https://orcid.org/0000-0001-5084-8008

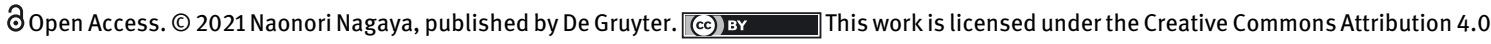
International License. 


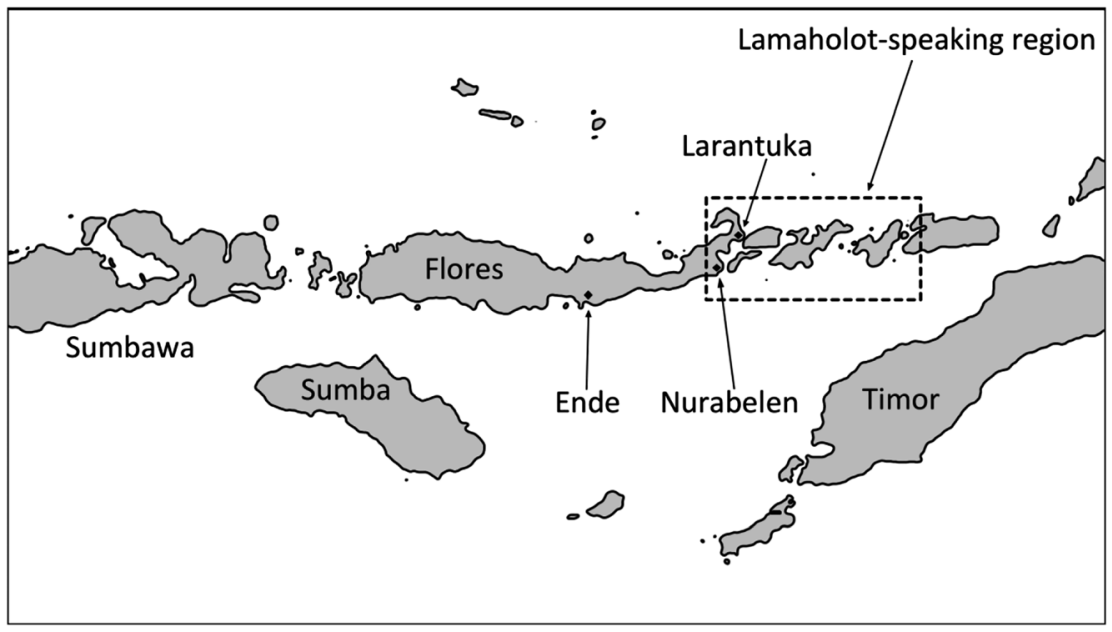

Map 1: Flores Island.

(1) a. Mountain-sea axis

rae 'the direction of a (specific) mountain'/'mountainward'

lau 'the direction of the sea'/'seaward'

wali 'a direction parallel with the coast'

b. Up-down axis

teti 'up'/'upward'

lali 'down'/'downward'

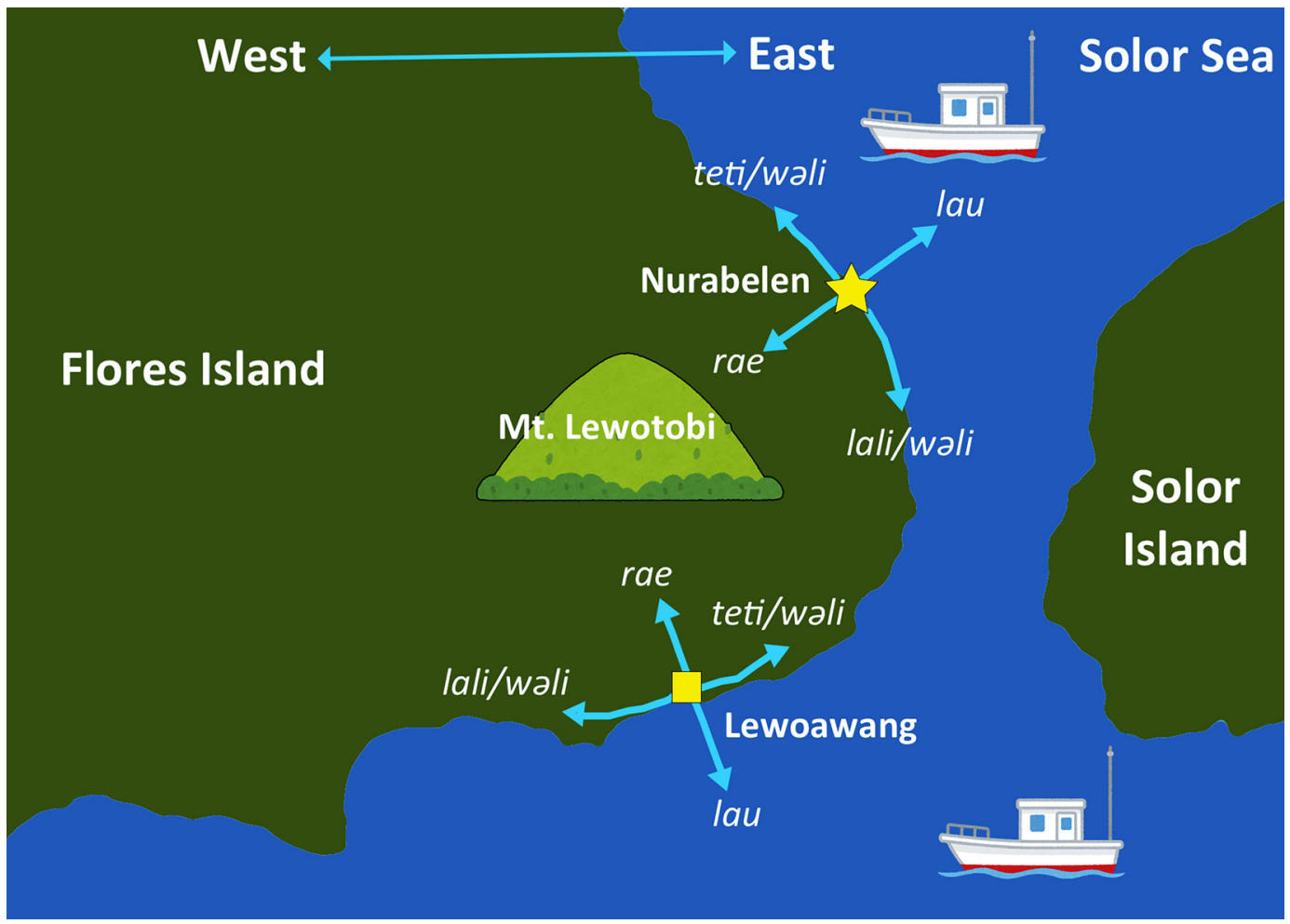

Map 2: Mt. Lewotobi (the illustrations in Map 2 and Figures 3 and 4 are adopted from Irasutoya [http://www.irasutoya.com/]). 


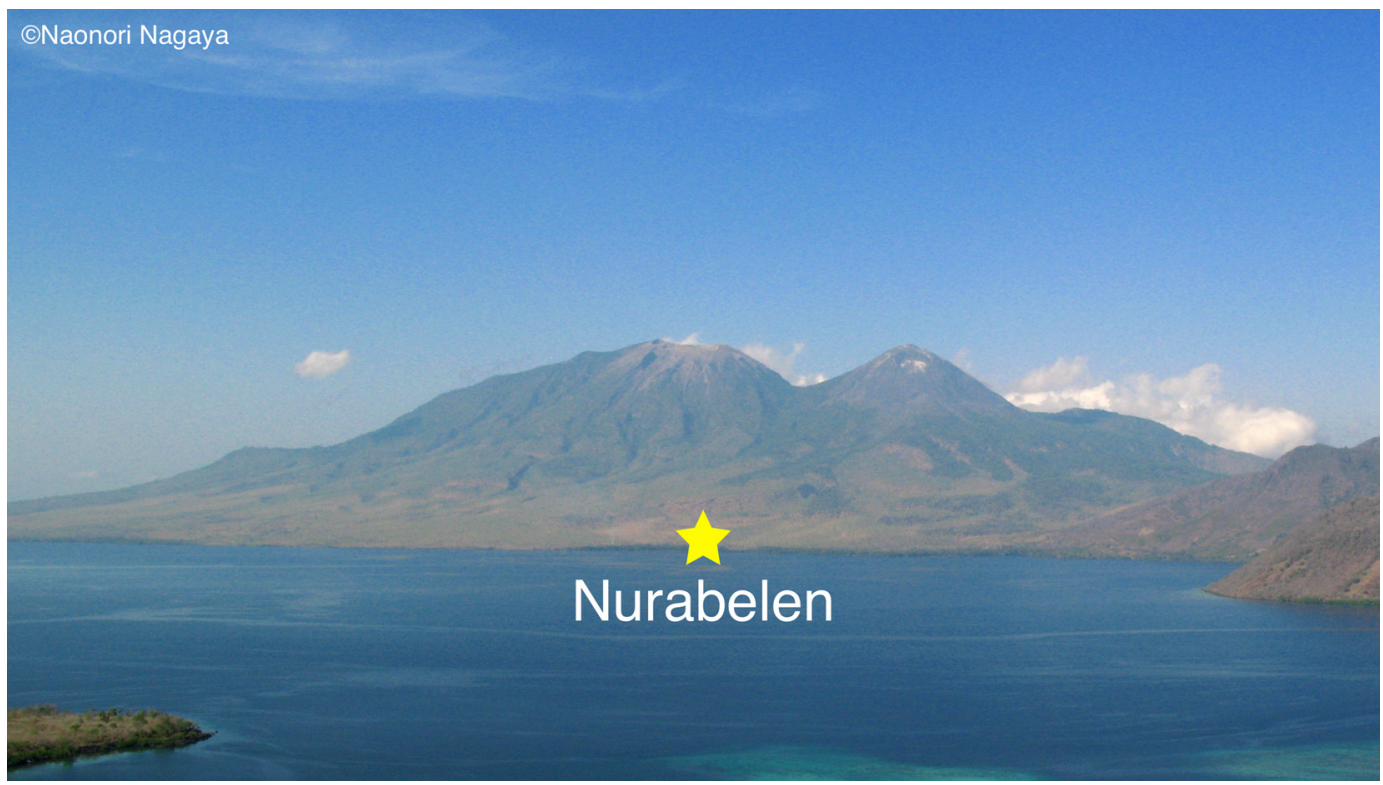

Figure 1: Mt. Lewotobi and Nurabelen.

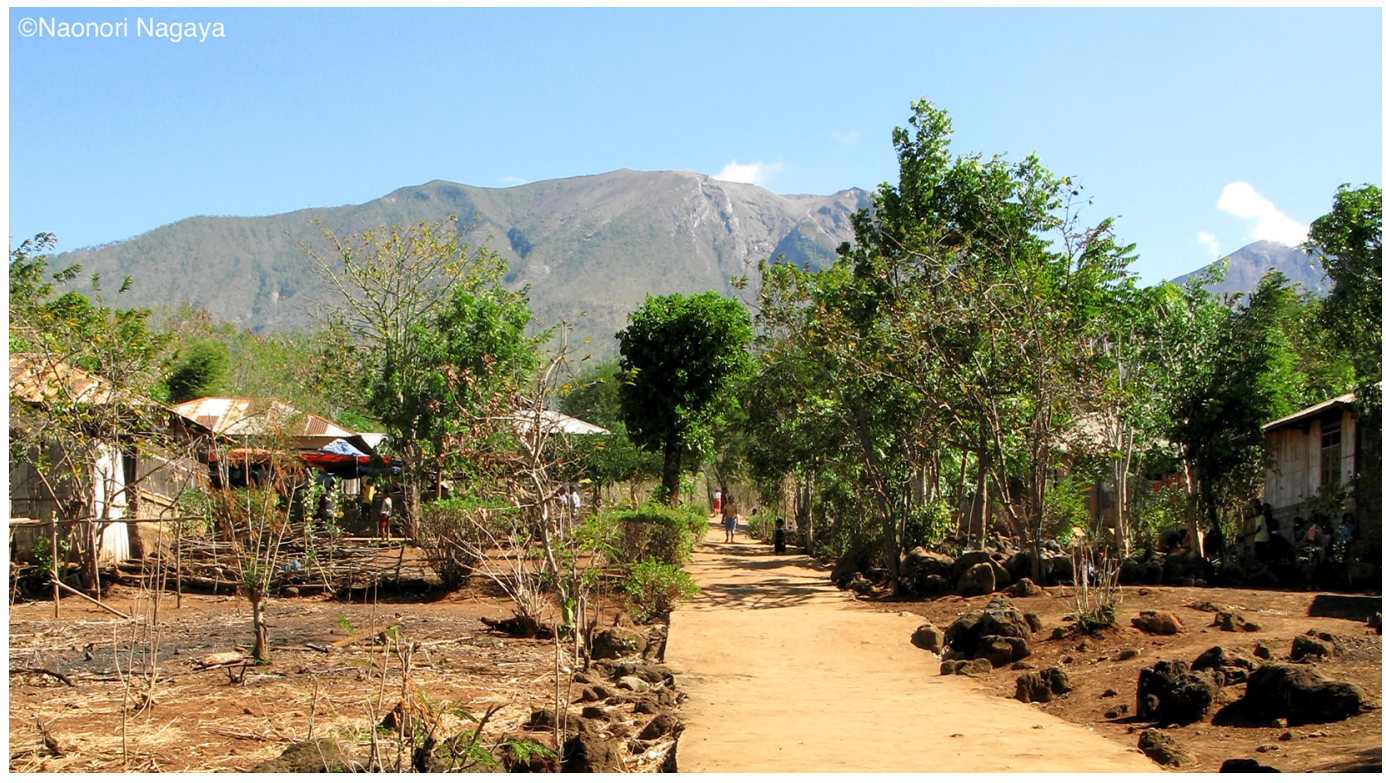

Figure 2: View of Mt. Lewotobi from Nurabelen.

The main function of these directionals is that of specifying the direction of persons, objects, and locations from the speaker's location with regard to a local landmark such as a (specific) mountain or the sea (see Section 3), as in (2). ${ }^{1}$

$\begin{array}{llll}\text { (2) Hugo biho } & \text { rae } & \text { lano?. } \\ \text { Hugo } & \text { cook } & \text { DIR.MT house }\end{array}$

'Hugo is cooking in the house that is mountainward (from me).'

1 Examples follow the Leipzig Glossing Rules. Abbreviations used: 1/2/3 first/second/third person; COAST parallel to coast; DEM demonstrative; DIR directional; DIS distal; DOwN downward; IAM iamitive; MT mountainward; NMLz nominalization; PL plural; SEA seaward; SG singular; uP upward. 
In (2), the directional rae is used as a preposition, syntactically marking the following NP lano? 'the house' as an adjunct. Semantically, it indicates that the referent of the NP 'house' is located in the direction of a particular mountain from the speaker's perspective. ${ }^{2}$

Austronesian languages are known for having such landmark-based spatial terms; the Balinese spatial language is probably the most well-known case (Wassmann and Dasen 1998). Indeed, the contrast between the land and the sea is "the fundamental axis of orientation in Austronesian societies" (Adelaar 1997: 53) and can even be traced back to Proto-Austronesian. Studies of such geocentric spatial systems have a long history of descriptive, historical, and comparative research and have been attracting increasing attention, as summarized in Blust (2013: 305-314, 495-498), as well as in two general collections on this topic (Bennardo 2002; Senft 1997). Substantial crosslinguistic diversity in spatial reference across these languages has been well documented in the literature.

This paper looks into the language-internal diversity of the Lamaholot directional system. Although landmark-based spatial terms are common across Austronesian languages, this language displays considerable language-internal variation that deserves special attention. This paper first considers how the volcanic island topography of Flores is embedded in the Lamaholot lexicon and sociocultural practices (Section 2), and then identifies and describes three important types of variation. First, the interpretation of directionals varies considerably depending on speakers' construals of the landscape (Section 3). Second, the topographic environment plays an important role in the use of the Lamaholot geocentric frame of reference (FoR), yielding variation among communities and individual speakers (Section 4). Third, directionals exhibit morphosyntactic versatility, appearing in a wide range of syntactic contexts (Section 5). This paper argues that, taken together, these variations result from a complex interplay of the topographic environment, sociocultural practices, language uses, and linguistic repertoire, making a strong case for the Sociotopographic Model of spatial language (Palmer 2015; Palmer et al. 2017, 2018).

\section{Spatially anchored lexicon and social practices}

The Lamaholot directional system in (1) is embedded in, and tightly interwoven with, sociocultural and linguistic practices in Lamaholot-speaking communities. Here we consider two major cases. First, the spatial orientation represented by directionals permeates Lamaholot lexicalization patterns to the extent that, in motion verbs, the directional concepts in (1) are lexicalized along with other spatial concepts. To begin with, Lamaholot has three words that roughly correspond to the English deictic verb come: hau 'come from the direction of rae/teti', haka 'come from the direction of lali', and dai 'come from the direction of wali/lau'. Different deictic verbs correspond to different source directions. In addition, there are specialized verbs of motion for each direction: gere 'move upward', lodo 'move downward', habã 'move mountainward', and lua 'move seaward'. Terms for directions in clockwise and counterclockwise circular motion have their own name (for example, teti dai rae nai 'a counterclockwise circular motion from the sea to the mountain'). Thus, the directional system plays a crucial role in lexicalization patterns of motion verbs.

Second, the up-down axis represents the cosmology of Lamaholot speakers. According to Lamaholot mythology, the Lamaholot world is structured and governed by two gods, the father god lora-wulã 'sun-moon' and the mother goddess tana-ekã 'earth-ground', while human beings, ata dikã 'right/proper people', are sandwiched between the two divine worlds. The father god is in the teti 'upward' world, while the mother goddess is in the lali 'downward' world.

As a consequence, there are a number of sociocultural practices mediated by the directional system. Such practices include sleeping positions, religious rituals, and conventionalized greetings. For example,

2 As will be discussed in Section 4.2, the mountain that rae refers to is conventionally determined and can vary from village to village. It refers to Mt. Lewotobi when the speaker is in Nurabelen but can be used to refer to another mountain when a speaker is in another village. 
Lamaholot speakers sleep in the position of kotə? rae lei lau 'head mountainward, legs seaward': a person's head should be mountainward, and legs seaward. This is also the direction of burying bodies in tombs and of holding sacrificial animals in religious ceremonies. In addition, counterclockwise motion, such as the abovementioned teti dai rae nai 'a counterclockwise circular motion from the sea to the mountain', is considered sacred and is exercised in rituals, for example, for celebrating a newly built house. It is also of cultural significance in architecture and woodworking: the direction of the lumber used for houses and furniture must align with the designated directions in the sacred counterclockwise motion.

Furthermore, the Lamaholot directional system is associated with, and reinforced by, conventionalized greetings. In this language community, expressions like mo tea mai 'Where are you going?' and mo tea gwali 'Where are you coming from?' are conventionalized greetings. ${ }^{3}$ People return these greetings by shouting out either a directional or one of the above-mentioned motion verbs.

To summarize, the directional system in Lamaholot is embedded in sociocultural and linguistic practices in this village. ${ }^{4}$ These sociocultural practices, in addition to the volcanic island topography, make it virtually impossible to live in the village without activating the spatial concepts represented by this directional system.

\section{Construals of landscape and diversity in interpretation}

Directionals provide a coordinate system for geocentric FoR and are employed for expressing a projective locative relationship between figure and ground (Bohnemeyer and O'Meara 2012; Danziger 2010; Levinson 1996, 2003; Palmer 2015). Importantly, this use of directionals exhibits great diversity in interpretation: the axes of this coordinate system point to different directions depending on speakers' construals of the landscape.

For illustrative purposes, three major construals are distinguished here: (a) the local scale with implicit ground, (b) the global scale with implicit ground, and (c) the explicit ground construal. In (a) and (b) the ground is the speaker and is not overtly expressed, while in (c) the ground is not the speaker and is overtly expressed. The difference between (a) and (b) is whether spatial configuration is construed within the context of the speaker's village, as in (a), or on the island-wide scale, as in (b). Although all three construals involve locating a figure by projecting a domain off a ground, directionals refer to different directions in different construals.

\subsection{Local scale with implicit ground}

The directionals in (1) are frequently employed for spatial reference on the local scale with implicit ground, in which the ground is interpreted as the speaker, as in (3) and (4).

$\begin{array}{llll}\text { na } & \text { turu } & \text { teti } & \text { lano?. } \\ \text { 3SG } & \text { sleep } & \text { DIR.up } & \text { house }\end{array}$

'He/she is sleeping in the house that is upward (from me).'

(4)

\begin{tabular}{|c|c|c|c|}
\hline Hugo & wali & layo? & $\begin{array}{l}n-a i \\
3 s c-\sigma o\end{array}$ \\
\hline & & & \\
\hline
\end{tabular}

'Hugo already went to the house which is in a direction parallel with the coast.'

3 This conventionalized custom is characteristic of not only Lamaholot-speaking communities but also the Mekong-Mamberamo linguistic area (Gil 2015: 280-282).

4 Other semantic areas closely associated with directionals include wind names and fishing/navigation terms (Barnes 1996). The fact that directional concepts conveyed by directionals are associated with specific semantic fields such as religious rituals, fishing, and sea navigation suggests that spatial reference strategies may vary according to sociolinguistic factors such as age, gender, and occupation (Palmer et al. 2017: 201, Palmer et al. 2018: 20). 
In these examples, the directionals are used for specifying the direction of the referent of the following NP from the implicit ground object, that is, the speaker. In (3), teti indicates that the house is upward-at a vertically higher position-while wali in (4) shows that the house is located in a direction parallel with the coast, not specifying either the teti or lali direction (Map 2). ${ }^{5}$

On the local scale, the speaker is the implicit ground, and thus the choice of directionals depends on the location of the speaker. For example, (3) is felicitous when the speaker is at a vertically lower position than the house, but (5) is instead used when the speaker is at a vertically higher position than the house.

$\begin{array}{llll}\text { na } & \text { turu } & \text { lali } & \text { layo?. } \\ 3 \mathrm{sg} & \text { sleep } & \text { DIR.Down } & \text { house }\end{array}$

'He/she is sleeping in the house that is downward (from me).'

Note that, on this scale, directionals cannot be employed for describing the position of an entity on a tabletop scale (cf. the explicit ground construal in example (14) in Section 3.3). For example, one cannot use (6) for referring to a table when it is located in the speaker's personal sphere; it is only felicitous when it is far from the speaker.

$$
\begin{aligned}
& \text { mo ta?o tas mo?e } \quad \text { rae medza. } \\
& \text { 2sG put bag 2sG.NMLz DIR.MT table } \\
& \text { 'Put your bag on the table that is mountainward (from me)!' }
\end{aligned}
$$

The use of the directional rae 'mountainward' in (6) implies that the table is located far from the speaker. To avoid such an implication, one needs to employ a demonstrative rather than a directional, as in (7).

$$
\begin{aligned}
& \text { mo ta?o tas moßẽ pe: medza. } \\
& \text { 2sG put bag 2SG.NMLZ DEM.DIS table } \\
& \text { 'Put your bag on that table!' }
\end{aligned}
$$

Importantly, on the local scale, the mountain-sea and the up-down axes are independent from each other. For this reason, different construals of the same situation can lead to the use of different directionals. In sentence (8), for instance, $m \tilde{a}$ 'garden' can be marked with either rae or teti.

$\begin{array}{llll}r a & \text { kriã } & \text { rae/teti } & \text { mã. } \\ \text { 3PL } & \text { work } & \text { DIR.MT/DIR.UP } & \text { garden }\end{array}$

'They work in the garden that is mountainward/upward (from me).'

In (8), mã 'garden' is marked with rae 'mountainward' when its location is understood relative to the mountain, but as teti 'upward' when its vertical position is at issue.

\subsection{Global scale with implicit ground}

On the global scale or when spatial configuration is understood to be outside the speaker's village or territory, the directionals in (1) do not refer to topographical concepts but rather to conventionalized directions in Lamaholot speakers' interpretation of the topographic environments on Flores Island, as in (9).

(9) a. Mountain-sea axis

$$
\begin{aligned}
& \text { rae 'speaker's own village', 'Flores Island' } \\
& \text { lau 'overseas' }
\end{aligned}
$$

b. East-west axis

teti 'toward the eastern tip of the island'

lali 'toward the western tip of the island'

5 The directional wali also means 'thither side, other side' when it is contrasted with the locative ia 'hither side, this side' (Nagaya 2011: 572-578) 
There are three notes to make about (9). First, the directional woli 'a direction parallel with the coast' is not used in this context. Second, the mountain-sea axis is still based on the physical geographical characteristics of the island, whereas the up-down axis is mapped to the east-west axis. ${ }^{6}$ Third, like the local scale with implicit ground discussed in Section 3.1, the implicit ground is the speaker, and the choice of directionals on this scale depends on the location of the speaker. ${ }^{7}$

Examples of directionals on the global scale are given in (10) and (11). These examples would be spoken by someone located in Nurabelen.

$$
\begin{array}{lllll}
\text { ba? } & \text { go?ẽ } & \text { kriã } & \text { lau } & \text { Malaysia. } \\
\text { father } & \text { 1SG.NMLZ } & \text { work } & \text { DIR.SEA } & \text { Malaysia }
\end{array}
$$

'My father works in Malaysia, which is seaward (from me).'

$\begin{array}{llll}r a & \text { lali } & \text { Ende } & \text { haka. } \\ \text { 3PL } & \text { DIR.Down } & \text { Ende } & \text { come }\end{array}$

'They came from Ende, which is toward the western tip of Flores (lit. downward) (from me).'

In (10), Malaysia is marked with lau 'the direction of the sea', because it is overseas and reachable from Flores only by ship. In (11), Ende is preceded by lali 'downward'. Ende is a large city in Central Flores (Map 1). Locations along the roads toward the western tip of Flores receive this marking.

Importantly, directionals are markers of local landmarks on the local scale but represent Lamaholot speakers' cultural understandings of Flores on the global scale. First, teti and lali do not exactly correspond to the English cardinal terms east and west but rather represent both topographically motivated and culturally defined directions (Map 2). Second, teti and lali do not imply vertically high or low directions. For example, on the local scale, teti refers to higher ground, as in (3), but it does not have this entailment on the global scale, as in (12). Larantuka is at the same height above sea level as, but is located farther east than, Nurabelen (Map 1). That is why it is marked with teti 'upward'.

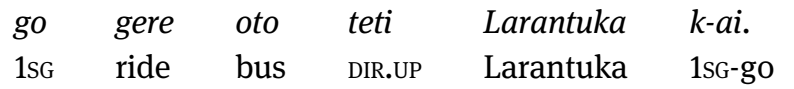

'I took a bus to Larantuka, which is upward (from me).'

\subsection{Explicit ground}

When the ground is not the speaker and is overtly expressed, directionals form a landmark-based coordinate system, represented in Figure 3. In this landmark-based coordinate system, two axes, the rae-lau and the tetilali axes, bisect at the anchor point marked by the symbol " $\times$ ”. This coordinate system is used for offering bearings for geocentric FoR.

As seen in Figure 3, the directionals rae and lau refer to 'the direction of the mountain' and 'the direction of the sea', respectively, as they do on the local and global scales. In contrast, the up-down axis is mapped onto the coastal dimension. Here, the contrast between the mountain-sea and up-down axes is lost: the two distinct axes are mapped onto a single flat ground plane, at right angles to each other (but see Section 4.2). The directional wali 'parallel with the coast' is not used in this construal.

6 The reason teti 'upward' and lali 'downward' correspond to 'east' and 'west', respectively, is unknown at this stage. But, as one of the reviewers commented, it is very common for geographically anchored directionals to be conventionalized on a larger scale. See François (2004) for related issues in Oceanic languages.

7 For example, (11) is felicitous only when the speaker is located east of Ende. If the speaker is located west of Ende, the sentence $r a$ teti Ende hau 'They came from Ende, which is toward the eastern tip of Flores' is used instead. 

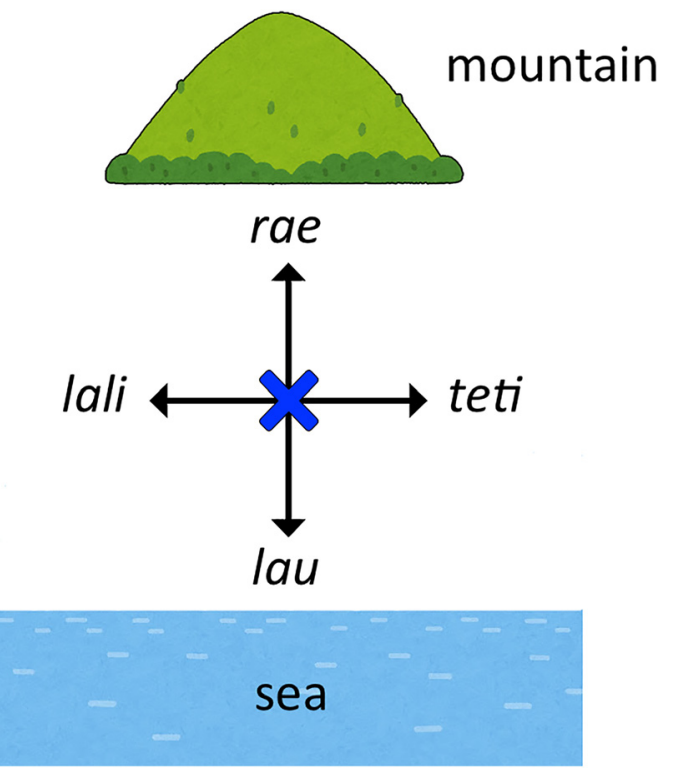

Figure 3: Coordinate system formed by directionals.

This coordinate system is imposed on the figure-ground scene by the geographic environment regardless of the speaker's position. In Nurabelen, for example, the position of the speaker's father represented in Figure 4 can be expressed as in (13).

$$
\begin{array}{llllll}
\text { ba go? } & \text { pe: } & \text { kadzo? } & \text { teti } & \text { papa } & \text { hau. } \\
\text { father 1SG.NMLZ } & \text { DEM.DIS } & \text { tree } & \text { DIR.UP } & \text { side } & \text { come } \\
\text { 'My father is upward of that tree.' } & & &
\end{array}
$$

This landmark-based FoR can be employed not only on an intra-village scale, as in (13), but also on a tabletop scale, as in (14).

(14) si?a taru pe: kecap lau papa dai.

salt place DEM.DIS soy.sauce DIR.SEA side come

'The salt is placed seaward of that soy sauce.'

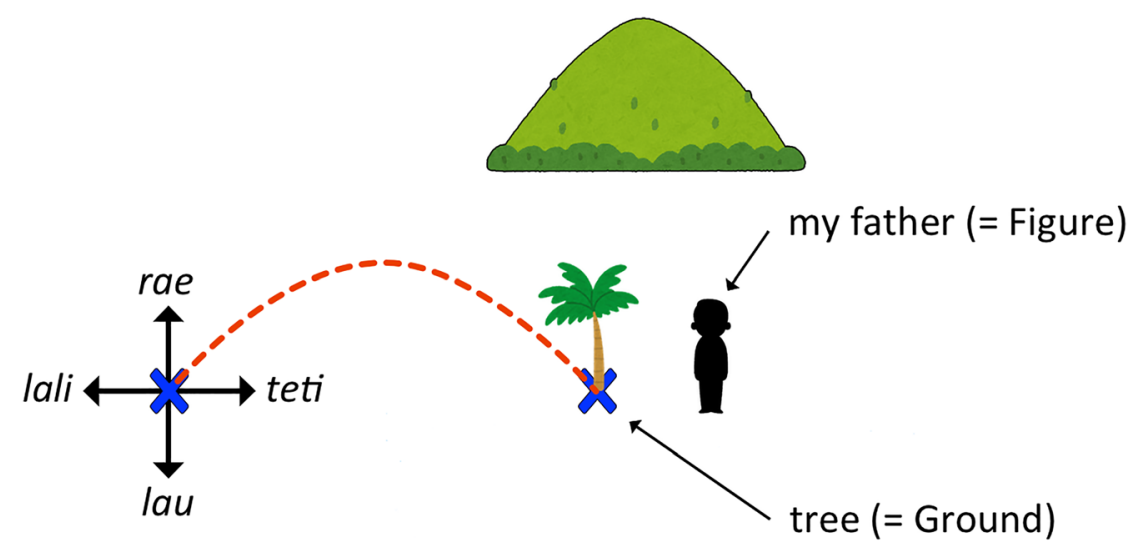

Figure 4: Spatial configuration expressed in (13). 


\subsection{Summary}

In this section, it was shown that directionals in Lamaholot point to different directions depending on how speakers construe spatial relationships. Three different construals are distinguished: the local scale with implicit ground, the global scale with implicit ground, and the explicit ground construal. For example, teti can be used to refer to 'upward' on the local scale, 'the direction toward the eastern tip of Flores Island' on the global scale, and a specific angle of the coordinate system in Figure 3. This represents not only lexical polysemy but also language-internal variation induced by speakers' construals of the landscape. Different meanings of directionals represent different modes of interacting with the landscape.

\section{The role of the topographic environment}

In the previous section it was shown that the geocentric directional system in Lamaholot conveys diverse meanings depending on speakers' construals of the landscape. In this section, it is argued that the topographic environment in which Lamaholot is spoken plays a significant role in shaping spatial representations. More specifically, the island topography of Flores enables the dominance of geocentric FoR in Lamaholot (Section 4.1) and affects the interpretation of this topographically anchored FoR system (Section 4.2). This provides support for the environment-sensitivity of spatial reference systems and the Topographic Correspondence Hypothesis, which postulates a correlation between the specific features of a system of spatial reference in geocentric/ absolute FoR and key salient features of the topography of the language locus (Palmer 2015).

\subsection{Dominance of geocentric FoR}

The role of the topographic environment in the Lamaholot spatial reference system can be observed most prominently in the dominance of geocentric FoR strategies in speech communities of this language. It is crosslinguistically common for a language to allow for more than one spatial reference strategy (Levinson 2003; Levinson and Wilkins 2006). However, Lamaholot shows a strong preference for geocentric FoR. In fact, geocentric FoR is the only versatile and productive FoR in this language: relative FoR is not available, and (non-geocentric) intrinsic FoR is restricted in terms of what can serve as the ground. ${ }^{8}$ Example (15) illustrates the fact that it is not possible to employ relative FoR in Lamaholot. ${ }^{9}$

$$
\begin{aligned}
& \text { *bal pe: kursi wənã. } \\
& \text { ball DEM.DIS chair right.hand } \\
& \text { Intended for 'The ball is to the right of that chair.' }
\end{aligned}
$$

This is because wənã 'right' in (15) is only a body part noun meaning 'right hand', and it is not pragmatically felicitous to say that nonhuman artifacts like chairs have hands.

In contrast, (non-geocentric) intrinsic FoR is available in Lamaholot, projecting a coordinate system with body part nouns, such as wanã 'right hand', mekĩ 'left hand', wãhã 'front', and pure? 'back'. See (16) and (17).

$$
\begin{aligned}
& \text { tapo dẽ pe: gredza wãhã =nə. } \\
& \text { palm.tree stand DEM.DIS church front }=\text { NMLZ } \\
& \text { 'The palm tree stands in front of that church.' }
\end{aligned}
$$

8 Lamaholot also lacks cardinal direction terms.

9 The body part noun wənã 'right hand' is the reflex of the Proto Malayo-Polynesian word *ka-wanan 'right, right hand'. Its cognates in other languages (e.g., kanan in Indonesian and Tagalog) are readily used as spatial relators in relative FoRs. Note that wənã 'right hand' can also be used to refer to other body parts with left-right symmetry, as in mata wənã 'right eye' and lei wənã 'right leg'. 


$$
\begin{array}{llrl}
\text { Nia tobo pe: } & \text { Tanti } & \text { mekĩ. } \\
\text { Nia sit DEM.DIs } & \text { Tanti } & \text { left.hand } \\
\text { 'Nia is seated to Tanti's left.' }
\end{array}
$$

In (16), the body part noun wãhã 'front' indicates that the search domain for the palm tree is projected from the front (i.e., entrance) of the church. Likewise, in (17), mekĩ 'left hand' means that Nia is seated in the nearby area projected from Tanti's left hand..$^{10}$

Importantly, within this type of intrinsic FoR, only human beings, animals, vehicles, and buildings with an explicit orientation (e.g., an entrance) can be the ground. This is because these body part terms can only refer to intrinsic parts of such entities. In particular, wənã 'right hand' and mekĩ 'left hand' are exclusively used for human beings. Compare (17) and (18).

$$
\begin{aligned}
& \text { *tapo deĩ pe: gredza mekĩ. } \\
& \text { palm.tree stand DEM.DIs church left.hand } \\
& \text { Intended for 'The palm tree stands to the left of that church.' }
\end{aligned}
$$

The intended meaning in (18) can only be felicitously expressed using directionals, as in (19).

$$
\begin{array}{llllll}
\text { tapo deĩ pe: } & \text { gredza } & \text { lau } & \text { papa } & \text { dai. } \\
\text { palm.tree stand } & \text { DEM.DIS } & \text { church } & \text { DIR.SEA } & \text { side } & \text { come } \\
\text { 'The palm tree stands seaward of that church.' } &
\end{array}
$$

Furthermore, the use of wənã 'right hand' and mekĩ 'left hand' is limited to situations in which figure and ground are adjacent to each other. Thus, a spatial configuration of the type depicted in (17) is more commonly expressed with directionals, as in (20).

$\begin{array}{lllll}\text { Nia tobo pe: } & \text { Tanti lali } & \text { papa } & \text { haka. } \\ \text { Nia sit DEM.DIs } & \text { Tanti DIR.Down } & \text { side } & \text { come } \\ \text { 'Nia is seated downward of Tanti.' } & \end{array}$

Thus, Lamaholot speakers in Nurabelen almost exclusively employ the directional-based geocentric FoR system for spatial reference. I consider this to be an influence of the topographic environment in which this language is spoken. This village is located along the coastal area between Mt. Lewotobi and the Solor Sea. The villagers are farmers and/or fishers. In these subsistence modes, they intensively engage with the topographic environment on a daily basis. A preference for geocentric/absolute FoR in rural settings is well attested in the literature (Majid et al. 2004; Palmer et al. 2017; Pederson 1993; Pederson et al. 1998).

\subsection{Topographic influence on geocentric FoR}

The external physical aspects of the topographic environment affect the use of the Lamaholot geocentric FoR system, just as geocentric FoRs in other languages can be sensitive to the environment (Bohnemeyer and O’Meara 2012; Levinson 2003; Palmer 2015; Wassmann and Dasen 1998). To begin with, it is crucial to emphasize that the location of a (particular) mountain is considered to be the most salient landmark in this coordinate system. For this reason, the correspondence between Lamaholot directionals and cardinal directions may change depending on the location of the speaker. In Nurabelen, for example, the landmark mountain is in the west, and the directionals rae, lau, teti, and lali correspond to the cardinal directions 'west', 'east', 'north', and 'south', respectively. But they refer to 'north', 'south', 'east', and 'west' in the village of Lewoawang, in which the landmark mountain is in the north (Map 2). In addition, the two axes employed for geocentric FoR, namely, the mountain-sea axis and the up-down axis, are not exactly orthogonal. In particular, the up-down axis can be flexibly adjusted and curved according to the physical shape of the coastline (Map 2).

10 The example in (17) does not have a relative FoR interpretation. 
Furthermore, the mountain-sea axis is determined by local topography. The directionals rae 'the direction of a (specific) mountain' and lau 'the direction of the sea' can possibly refer to different directions in different villages. In Nurabelen, which is sandwiched by Mt. Lewotobi and the Solor Sea, the directional rae points in the direction of Mt. Lewotobi, the one and only twin volcanic mountain in the village. However, there are at least four cases in which this simple geographical condition is not met: (a) a village is surrounded by more than one mountain, (b) more than one side of a village is adjacent to the sea, (c) a village is not adjacent to the sea, and (d) in foreign lands. In case (a), the mountain which serves as the mountain to which rae refers in this system is conventionally determined and can vary from village to village. In cases (b) and (c), lau simply refers to the opposite direction to rae, as defined above. Finally, in case (d), in a foreign land, it is the speaker's responsibility to determine which mountain is used as the landmark, possibly resulting in variation among communities and individual speakers. ${ }^{11}$

Importantly, these topography-induced features of the Lamaholot FoR system are characteristic of what Bohnemeyer and O'Meara (2012) call "landmark-based", a subclass of geocentric FoRs. In the literature of Austronesian languages, such a system has often been labeled “absolute” (e.g., Palmer 2015; Senft 2006). In the classification adopted here (Bohnemeyer and O'Meara 2012: 218-220), however, landmark-based frames of the Lamaholot type are analyzed as intrinsic rather than absolute because they are not fully abstracted out of landscape features and they do not remain constant outside the village.

\section{Morphosyntactic versatility}

Directionals in Lamaholot exhibit morphosyntactic versatility, occurring in different syntactic contexts. ${ }^{12}$ On the one hand, directionals can be used as locative adverbials, prepositions, and verbs, as in (21), (22), and (23), respectively.

(21) Hugo tei rae.

Hugo live DIR.MT

'Hugo lives mountainward (from me).'

$$
\text { Hugo tei rae lano?. }
$$

Hugo live DIR.MT house

'Hugo lives in the house that is mountainward (from me).'

$$
\begin{aligned}
& \text { Hugo rae }=a ? . \\
& \text { Hugo DIR.MT }=3 \mathrm{sG} \\
& \text { 'Hugo (decided to) remain mountainward (from me).' }
\end{aligned}
$$

In (21), the directional rae is used as a locative adverb expressing the location of the action of living. In (22), the same directional is used as a preposition to introduce the NP lano? 'house' into the clause. In (23), the derived verb $r a e=a$ ? means that Hugo decided to remain mountainward. In this use, the indexing enclitic is obligatory.

On the other hand, when nominalized, directionals are used as noun modifiers and referential expressions, as in (24) and (25), respectively.

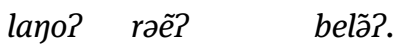

$$
\begin{aligned}
& \text { house DIR.MT.NMLZ big } \\
& \text { 'The house located mountainward is big.' }
\end{aligned}
$$

11 According to my language consultants, who have worked in Malaysia with other Lamaholot speakers, the best way to avoid this type of confusion is to speak Indonesian, the national language of the Republic of Indonesia, rather than Lamaholot.

12 See Nagaya (2011) for a full description of the morphosyntax of directionals in this language. 


$$
\begin{aligned}
& \text { rəễ } \quad \text { belãP. } \\
& \text { DIR.MT.NMLZ big } \\
& \text { 'The one located mountainward is big.' }
\end{aligned}
$$

In (24), the nominalized directional rəễ? specifies the direction of the NP lano? 'house'. In (25), it refers to something located mountainward, whose referent is recoverable from the context.

To conclude, directionals can appear in a wide range of syntactic contexts. This morphosyntactic versatility is important, because it allows these topographic spatial terms to be used more frequently than other syntactically fixed spatial terms, such as locative nouns, making this geocentric system (and geocentric reference) predominant among the linguistic repertoire in this language. ${ }^{13}$

\section{Conclusions}

This paper has shown that spatial references with the directional system in Lamaholot display intriguing variations at various levels and that they can be ascribed to a complex interplay of the topographic environment, sociocultural practices, language uses, and linguistic repertoire, as assumed in the Sociotopographic Model. The volcanic island topography of Flores is embedded in sociocultural practices in Lamaholot-speaking communities. Such practices are implemented by means of the directional system, which shows diversity in its interpretation depending on speakers' construals of the landscape. The morphosyntactic versatility of directionals makes it easier for them to appear in a wide variety of constructions. Thus, the directional system in Lamaholot makes a compelling case for the Sociotopographic Model approach to spatial language.

Acknowledgments: I am thankful to Alice Gaby, Bill Palmer, and two anonymous reviewers for valuable comments and criticism that have helped improve the paper. Any errors that remain are my responsibility.

Research funding: Research reported in this article was supported by JSPS KAKENHI Grant Numbers JP19H01264, JP21H00528, and JP21K00522.

\section{References}

Adelaar, K. Alexander. 1997. An exploration of directional systems in West Indonesia and Madagascar. In Gunter Senft (ed.), Referring to space: Studies in Austronesian and Papuan languages, 53-81. Oxford: Clarendon Press.

Barnes, Robert Harrison. 1996. Sea hunters of Indonesia: Fishers and weavers of Lamalera. Oxford: Clarendon Press. Bennardo, Giovanni (ed.). 2002. Representing space in Oceania: Culture in language and mind. Canberra: Pacific Linguistics. Blust, Robert. 1993. Central and Central-Eastern Malayo-Polynesian. Oceanic Linguistics 32(2). 241-293.

Blust, Robert. 2013. The Austronesian languages, rev. edn. Canberra: Asia-Pacific Linguistics.

Bohnemeyer, Jürgen \& Carolyn O’Meara. 2012. Vectors and frames of reference: Evidence from Seri and Yucatec. In Luna Filipović \& Katarzyna M. Jaszczolt (eds.), Space and time in languages and cultures: Language, culture, and cognition, 217-249. Amsterdam: John Benjamins.

Danziger, Eve. 2010. Deixis, gesture, and cognition in spatial Frame of Reference typology. Studies in Language 34(1). 167-185. François, Alexandre. 2004. Reconstructing the geocentric system of Proto-Oceanic. Oceanic Linguistics 43(1). 1-31.

Gil, David. 2015. The Mekong-Mamberamo linguistic area. In Nick J. Enfield \& Bernard Comrie (eds.), The languages of mainland Southeast Asia: The state of the art, 266-355. Berlin: De Gruyter.

Levinson, Stephen C. 1996. Frames of reference and Molyneux's question: Crosslinguistic evidence. In Paul Bloom, Merrill F. Garrett, Lynn Nadal \& Mary A. Peterson (eds.), Language and space, 109-169. Cambridge, MA: MIT Press. Levinson, Stephen C. 2003. Space in language and cognition: Explorations in cognitive diversity. Cambridge: Cambridge University Press.

13 Palmer et al. (2017:486-487) report that the greater availability of grammaticized landscape terms in Marshallese corresponds to a higher proportion of geocentric references in this language than in Dhivehi, in which landscape terms are not well grammaticized and are only used as locative adjuncts. In Lamaholot, too, directionals show a relatively higher degree of grammaticization: they are employed not only as locative adverbs but also as prepositions and modifiers. 
Levinson, Stephen C. \& David P. Wilkins (eds.). 2006. Grammars of space: Explorations in cognitive diversity. Cambridge: Cambridge University Press.

Majid, Asifa, Melissa Bowerman, Sotaro Kita, Daniel B. M. Haun \& Stephen C. Levinson. 2004. Can language restructure cognition? The case for space. Trends in Cognitive Sciences 8(3). 108-114.

Nagaya, Naonori. 2011. The Lamaholot language of eastern Indonesia. Houston, TX: Rice University dissertation.

Palmer, Bill. 2015. Topography in language: Absolute frame of reference and the Topographic Correspondence Hypothesis. In Rik De Busser \& Randy J. LaPolla (eds.), Language structure and environment: Social, cultural, and natural factors, 177-226. Amsterdam: John Benjamins.

Palmer, Bill, Alice Gaby, Jonathon Lum \& Jonathan Schlossberg. 2018. Diversity in spatial language within communities: The interplay of culture, language and landscape in representations of space. In Stephan Winter, Amy Griffin \& Monika Sester (eds.), 10th International conference on geographic information science, 53:1-53:8 (GIScience 2018).

Palmer, Bill, Jonathon Lum, Jonathan Schlossberg \& Alice Gaby. 2017. How does the environment shape spatial language? Evidence for sociotopography. Linguistic Typology 21(3). 457-491.

Pederson, Eric. 1993. Geographic and manipulable space in two Tamil linguistic systems. In Andrew U. Frank \& Irene Campari (eds.), Spatial information theory: A theoretical basis for GIS, 294-311. Berlin: Springer-Verlag.

Pederson, Eric, Eve Danziger, David Wilkins, Stephen Levinson, Sotaro Kita \& Gunter Senft. 1998. Semantic typology and spatial conceptualization. Language 74(3). 557-589.

Senft, Gunter (ed.). 1997. Referring to space: Studies in Austronesian and Papuan languages. Oxford: Clarendon Press.

Senft, Gunter. 2006. Prolegomena to a Kilivila grammar of space. In Stephen C. Levinson \& David P. Wilkins (eds.), Grammars of space: Explorations in cognitive diversity, 206-229. Cambridge: Cambridge University Press.

Wassmann, Jurg \& Pierre R. Dasen. 1998. Balinese spatial orientation: Some empirical evidence of moderate linguistic relativity. The Journal of the Royal Anthropological Institute 4(4). 689-711. 